Article

\title{
Flavonol Glycosides: In Vitro Inhibition of DPPIV, Aldose Reductase and Combating Oxidative Stress are Potential Mechanisms for Mediating the Antidiabetic Activity of Cleome droserifolia
}

\author{
Amira Abdel Motaal 1,2,*他, Heba H. Salem ${ }^{3,4} \oplus$, Dalia Almaghaslah ${ }^{5}$, Abdulrhman Alsayari ${ }^{1}$, \\ Abdullatif Bin Muhsinah ${ }^{1}\left(\mathbb{D}\right.$, Mohammad Y. Alfaifi ${ }^{6}{ }^{(}$, Serag Eldin I. Elbehairi ${ }^{6,7}{ }^{(0)}$, \\ Ali A. Shati ${ }^{6}$ and Hesham El-Askary ${ }^{2}$ \\ 1 Department of Pharmacognosy, College of Pharmacy, King Khalid University, Abha 61441, Saudi Arabia; \\ alsayari@kku.edu.sa (A.A.); ajmohsnah@kku.edu.sa (A.B.M.) \\ 2 Department of Pharmacognosy, Faculty of Pharmacy, Cairo University, Cairo 11562, Egypt; \\ hesham.elaskary@pharma.cu.edu.eg \\ 3 Department of Biochemistry, Faculty of Pharmacy, Cairo University, Cairo 11562, Egypt; \\ haminsalem@kku.edu.sa \\ 4 College of Pharmacy, King Khalid University, Abha 61441, Saudi Arabia \\ 5 Department of Clinical Pharmacy, College of Pharmacy, King Khalid University, Abha 61441, Saudi Arabia; \\ damoazle@kku.edu.sa \\ 6 Department of Biology, Faculty of Science, King Khalid University, Abha 9004, Saudi Arabia; \\ alfaifi@kku.edu.sa (M.Y.A.); serag@kku.edu.sa (S.E.I.E.); aaalshati@kku.edu.sa (A.A.S.) \\ 7 Cell Culture Laboratory, Egyptian Organization for Biological Products and Vaccines, VACSERA Holding Company, \\ Giza 22311, Egypt \\ * Correspondence: aabdulmtaal@kku.edu.sa or a_motaal@hotmail.com; Tel.: +966-501533779
}

Received: 12 November 2020; Accepted: 5 December 2020; Published: 11 December 2020

check for updates

\begin{abstract}
Diabetes is a major health problem that is associated with high risk of various complications. Medicinal plants hold great promise against diabetes. The traditional use of Cleome droserifolia as an antidiabetic agent was correlated to its flavonol glycosides content. In the current study, five major flavonol glycosides appeared on the RP-HPLC chromatogram of the aqueous extract namely; quercetin-3-O- $\beta$-D-glucosyl-7-O- $\alpha$-rhamnoside (1), isorhamnetin-7-O- $\beta$-neohesperidoside (2), isorhamnetin-3-O- $\beta$-D-glucoside (3) kaempferol- $4^{\prime}$-methoxy-3,7-O- $\alpha$-dirhamnoside (4), and isorhamnetin3-O- $\alpha$-(4"-acetylrhamnoside)-7-O- $\alpha$-rhamnoside (5). The inhibitory activities of these compounds were tested in vitro against several enzymes involved in diabetes management. Only the relatively less polar methoxylated flavonol glycosides $(4,5)$ showed mild to moderate $\alpha$-amylase and $\alpha$-glucosidase inhibitory activities. Compounds $\mathbf{1}-\mathbf{4}$ displayed remarkable inhibition of dipeptidyl peptidase IV (DPPIV) enzyme ( $\mathrm{IC}_{50} 0.194 \pm 0.06,0.573 \pm 0.03,0.345 \pm 0.02$ and $0.281 \pm 0.05 \mu \mathrm{g} / \mathrm{mL}$, respectively) comparable to vildagliptin $\left(\mathrm{IC}_{50} 0.154 \pm 0.02 \mu \mathrm{g} / \mathrm{mL}\right.$ ). Moreover, these compounds showed high potential in preventing diabetes complications through inhibiting aldose reductase enzyme and combating oxidative stress. Both isorhamnetin glycoside derivatives $(2,3)$ exhibited the highest activities in aldose reductase inhibition and compound $2\left(\mathrm{IC}_{50} 5.45 \pm 0.26 \mu \mathrm{g} / \mathrm{mL}\right)$ was even more potent than standard quercetin $\left(\mathrm{IC}_{50} 7.77 \pm 0.43 \mu \mathrm{g} / \mathrm{mL}\right.$ ). Additionally, these flavonols exerted excellent antioxidant capacities through 2, 2-diphenyl-1-picrylhydrazil (DPPH) and ferric reducing antioxidant (FRAP) assays.
\end{abstract}

Keywords: diabetes; aldose reductase; DPPIV; antioxidant; flavonols; Cleome droserifolia 


\section{Introduction}

Diabetes mellitus is a metabolic disorder characterized by hyperglycemia and associated with disorders in metabolism because of insufficient insulin required by the body [1]. Alpha-amylase and $\alpha$-glucosidase are intestinal enzymes involved in the hydrolysis of starch into glucose and have a significant role in postprandial hyperglycemia. Hence, inhibition of these enzymes is crucial in the treatment of type 2 diabetes by delaying the digestion and absorption of disaccharides and starch [2]. Dipeptidyl peptidase IV (DPPIV) enzyme degrades the incretins, glucagon-like peptide 1 (GLP-1) and glucose-dependent insulinotropic polypeptide (GIP), that function by decreasing blood glucose through enhancement of insulin secretion and retardation of gastric emptying. Therefore, DPPIV inhibition has been used as an excellent target of new medications for type 2 diabetes [3]. Aldose reductase is an enzyme involved in catalyzing the reduction of glucose into sorbitol. During hyperglycemia associated with diabetes, significant quantities of sorbitol are produced due to the increased flux. Sorbitol accumulation participates in developing vascular and neurological complications of diabetes [4]. Thus, targeting this enzyme is of great benefit in the amelioration of diabetes complications.

Nowadays, the use of plant-derived natural products with therapeutic significance has attracted great attention due to their availability, affordability and relative safety. This motivates further search into traditional medicine to explore highly effective and safer natural anti-diabetic products that can probably hit several pathways. Cleome droserifolia (Forssk.) Del. herb (Cleomaceae) is known in the Middle East for diabetes treatment [5]. Various metabolites were isolated from the herb of this plant [6-12]. In addition, the antihyperglycemic activities of its different extracts were evaluated by several studies [8,13-17]. It was reported that $C$. droserifolia extract possessed a promising antidiabetic activity by a postprandial hypoglycemic effect and suppression to hepatic glucose output in the fasting state in albino rats. This was due to potentiation of peripheral and hepatic insulin sensitivity, and by diminishing intestinal glucose absorption [16]. The aqueous extract of $C$. droserifolia, standardized to contain not less than $1.5 \pm 0.06 \%$ of kaempferol- $4^{\prime}$-methoxy-3,7-dirhamnoside, showed a $63.3 \%$ activity of that of Metformin at $100 \mathrm{mg} / \mathrm{kg}$ body weight in rats, and raised the blood insulin level by $146.26 \%$ at this dose level [13].

We previously reported that the antidiabetic activity of the aqueous extract was higher than the ethanolic extract of Cleome droserifolia in cultured skeletal muscle cells and adipocytes. Treating muscle cells with the aqueous extract caused an increase in basal glucose uptake in a way comparable to insulin [6]. In another study, we demonstrated that the aqueous extract of C. droserifolia herb has a higher percent of the total flavonol glycosides $(78 \%)$ compared to the ethanolic extracts. Furthermore, this aqueous extract was tested in vivo, at three different doses in alloxan-induced diabetic rats, where the highest dose $(100 \mathrm{mg} / \mathrm{kg})$ exhibited about $63 \%$ of the antihyperglycemic activity of metformin [13]. Therefore, the current study aimed at isolating the major compounds from the C. droserifolia aqueous extract in addition to investigating the possible mechanisms underlying the previously shown antidiabetic activities using several in vitro enzyme inhibition assays. Moreover, the antioxidant potential of the C. droserifolia extract and the isolated compounds was assessed. This could propose vital lead compounds for the treatment of diabetes and prevention from its complications.

\section{Results and Discussion}

\subsection{RP-HPLC Fingerprint Chromatogram of the Aqueous Extract}

A chromatographic profile was prepared for the aqueous extract of $C$. droserifolia showing five major peaks (Figure 1). Compounds 1 and 2 were eluted first at Rt 4.9 and 6.5, respectively, followed by compounds 3, 4 and 5 at Rt 7.3,8.0 and $9.2 \mathrm{~min}$, respectively. This required the isolation of these major five compounds to explore their possible mechanisms of action, and to determine their contribution to the folk and previously proven antidiabetic activity of the holistic aqueous extract [6,13]. 


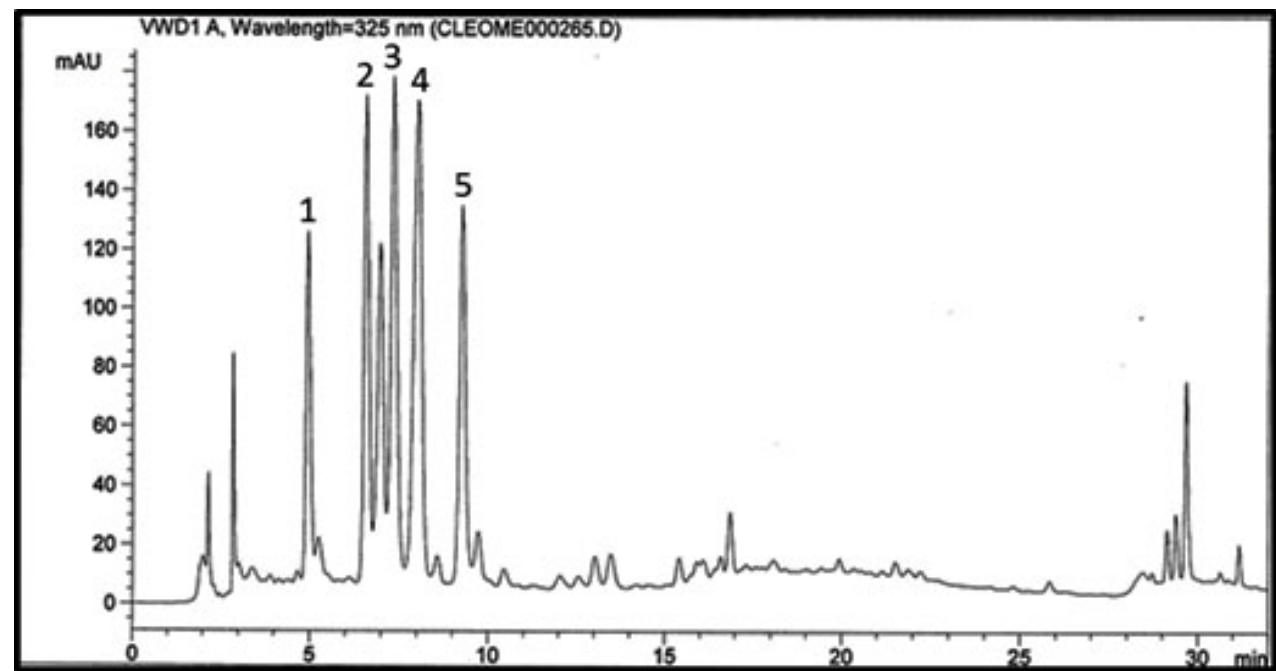

Figure 1. RP-HPLC fingerprint chromatogram of the aqueous extract of $C$. droserifolia showing peaks of major compounds: 1, 2, 3, 4 and 5 .

\subsection{Structural Elucidation of the Isolated Compounds}

Compound 1 was yellow amorphous powder; mp $195{ }^{\circ} \mathrm{C}$. The ${ }^{1} \mathrm{H}$ and ${ }^{13} \mathrm{C}-\mathrm{NMR}$ data showed the characteristic signals for a quercetin nucleus (Tables 1 and 2). The glycosidic characters in C-3 and C-7 positions were confirmed by the two anomeric protons $\left(\delta_{\mathrm{H}} 5.3\right.$ and $5.58 \mathrm{ppm} ; \delta_{\mathrm{C}} 102.52$ and $99.2 \mathrm{ppm})$ for glucose and rhamnose moieties, respectively, and the doublet $\left(\delta_{\mathrm{H}} 1.27 \mathrm{ppm} ; \delta_{\mathrm{C}} 16.68 \mathrm{ppm}\right)$ which was assigned to the methyl group of the rhamnose. All data matched those of a flavonol glycoside previously isolated from $C$. droserifolia $[9,17]$. Compound $\mathbf{1}$ was therefore identified as quercetin-3-O- $\beta$-D-glucosyl-7-O- $\alpha$-rhamnoside (Figure 2).

Table 1. ${ }^{13} \mathrm{C}-\mathrm{NMR}$ chemical shifts ( $\delta$ in ppm) for compounds $\mathbf{1 - 5}\left(\mathrm{CD}_{3} \mathrm{OD}\right.$ or DMSO-d $\left.6,100 \mathrm{MHz}\right)$.

\begin{tabular}{|c|c|c|c|c|c|}
\hline C & 1 & 2 & 3 & 4 & 5 \\
\hline 2 & 158.07 & 157.28 & 156.3 & 156.0 & 156.0 \\
\hline 3 & 134.38 & 133.75 & 132.7 & 134.5 & 134.4 \\
\hline 4 & 178.23 & 178.05 & 177.1 & 177.7 & 177.8 \\
\hline 5 & 161.38 & 161.34 & 161.1 & 160.1 & 161.8 \\
\hline 6 & 98.45 & 99.85 & 98.8 & 98.5 & 98.4 \\
\hline 7 & 162.17 & 162.05 & 165.1 & 161.6 & 160.4 \\
\hline 8 & 94.09 & 95.05 & 93.8 & 94.5 & 94.6 \\
\hline 9 & 156.57 & 156.45 & 156.9 & 157.7 & 157.6 \\
\hline 10 & 105.97 & 106.14 & 103.6 & 105.8 & 105.7 \\
\hline $1^{\prime}$ & 121.50 & 121.40 & 121.4 & 120.2 & 120.4 \\
\hline $2^{\prime}$ & 114.67 & 113.92 & 113.4 & 130.5 & 113.1 \\
\hline $3^{\prime}$ & 144.55 & 147.4 & 146.7 & 115.3 & 147.4 \\
\hline $4^{\prime}$ & 148.63 & 150.06 & 149.3 & 160.8 & 149.8 \\
\hline $5^{\prime}$ & 116.16 & 115.7 & 115.1 & 115.3 & 115.5 \\
\hline $6^{\prime}$ & 121.96 & 122.75 & 121.9 & 130.5 & 120.7 \\
\hline $1^{\prime \prime}$ & 102.52 & 101.18 & 100.8 & 101.8 & 101.3 \\
\hline $2^{\prime \prime}$ & 76.67 & 76.87 & 74.3 & 70.2 & 71.7 \\
\hline $3^{\prime \prime}$ & 74.33 & 74.79 & 76.4 & 70.5 & 70.1 \\
\hline $4^{\prime \prime}$ & 69.86 & 70.29 & 69.8 & 71.6 & 69.8 \\
\hline $5^{\prime \prime}$ & 77.02 & 77.96 & 77.3 & 70.0 & 68.0 \\
\hline $6^{\prime \prime}$ & 61.14 & 61.09 & 60.5 & 17.8 & 17.4 \\
\hline $1^{\prime \prime \prime}$ & 99.20 & 98.78 & & 99.3 & 99.4 \\
\hline $2^{\prime \prime \prime}$ & 70.28 & 70.5 & & 70.2 & 70.3 \\
\hline $3^{\prime \prime \prime}$ & 70.67 & 70.53 & & 70.3 & 69.9 \\
\hline $4^{\prime \prime \prime}$ & 72.20 & 72.07 & & 71.1 & 73.2 \\
\hline $5^{\prime \prime \prime}$ & 69.86 & 70.29 & & 69.7 & 67.5 \\
\hline $6^{\prime \prime \prime}$ & 16.68 & 18.38 & & 17.3 & 17.1 \\
\hline $\mathrm{OCH}_{3}-3^{\prime}$ & & & 55.6 & & 55.7 \\
\hline $\mathrm{OCH}_{3}-4^{\prime}$ & & & & 55.7 & \\
\hline $\mathrm{OCOCH}_{3}$ & & & & & 169.9 \\
\hline $\mathrm{OC}^{-} \mathrm{OCH}_{3}$ & & & & & 20.9 \\
\hline
\end{tabular}


Table 2. ${ }^{1} \mathrm{H}-\mathrm{NMR}$ chemical shifts ( $\left.\delta \mathrm{ppm}\right)$ for compounds $\mathbf{1 - 5}\left(\mathrm{CD}_{3} \mathrm{OD}\right.$ or DMSO- $\mathrm{d}_{6}, 400 \mathrm{MHz}, \mathrm{J}$ in $\left.\mathrm{Hz}\right)$.

\begin{tabular}{|c|c|c|c|c|c|}
\hline $\mathbf{H}$ & 1 & 2 & 3 & 4 & 5 \\
\hline 6 & $\begin{array}{c}6.47 \\
1 \mathrm{H}, \mathrm{d}, J=1.8\end{array}$ & $\begin{array}{c}6.46 \\
1 \mathrm{H}, \mathrm{d}, J=2.0\end{array}$ & $\begin{array}{c}6.18 \\
1 \mathrm{H}, \mathrm{d}, J=1.2\end{array}$ & $\begin{array}{c}6.44 \\
1 \mathrm{H}, \mathrm{d}, J=1.2\end{array}$ & $\begin{array}{c}6.45 \\
1 \mathrm{H}, \mathrm{d}, J=1.2\end{array}$ \\
\hline 8 & $\begin{array}{c}6.75 \\
1 \mathrm{H}, \text { br.s }\end{array}$ & $\begin{array}{c}6.86 \\
1 \mathrm{H}, \mathrm{d}, J=2.0\end{array}$ & $\begin{array}{c}6.41 \\
1 \mathrm{H}, \mathrm{d}, J=1.2\end{array}$ & $\begin{array}{c}6.77 \\
1 \mathrm{H}, \mathrm{d}, J=1.2\end{array}$ & $\begin{array}{c}6.78 \\
1 \mathrm{H}, \mathrm{d}, J=1.2\end{array}$ \\
\hline $2^{\prime}$ & $\begin{array}{c}7.74 \\
1 \mathrm{H}, \mathrm{d}, J=1.8\end{array}$ & $\begin{array}{c}7.96 \\
1 \mathrm{H}, \mathrm{d}, J=2.0\end{array}$ & $\begin{array}{c}7.94 \\
1 \mathrm{H}, \text { br.s }\end{array}$ & $\begin{array}{c}7.77 \\
2 \mathrm{H}, \mathrm{d}, J=8.4\end{array}$ & $\begin{array}{c}7.45 \\
1 \mathrm{H}, \mathrm{br.s}\end{array}$ \\
\hline $3^{\prime}$ & - & - & - & $\begin{array}{c}6.92 \\
2 \mathrm{H}, \mathrm{d}, J=8.4\end{array}$ & - \\
\hline $5^{\prime}$ & $\begin{array}{c}6.89 \\
1 \mathrm{H}, \mathrm{d}, J=8.5\end{array}$ & $\begin{array}{c}6.93 \\
1 \mathrm{H}, \mathrm{d}, J=8.4\end{array}$ & $\begin{array}{c}6.89 \\
1 \mathrm{H}, \mathrm{d}, \mathrm{J}=8.4\end{array}$ & $\begin{array}{c}6.92 \\
2 \mathrm{H}, \mathrm{d}, J=8.4\end{array}$ & $\begin{array}{c}6.93 \\
1 \mathrm{H}, \mathrm{d}, J=8.4\end{array}$ \\
\hline $6^{\prime}$ & $\begin{array}{c}7.6 \\
1 \mathrm{H}, \mathrm{dd}, J=1.8 \\
8.5\end{array}$ & $\begin{array}{c}7.57 \\
1 \mathrm{H}, \mathrm{dd}, J=2.1,8.5\end{array}$ & $\begin{array}{c}7.48 \\
1 \mathrm{H}, \mathrm{dd}, J=2.1,8.4\end{array}$ & $\begin{array}{c}7.78 \\
2 \mathrm{H}, \mathrm{d}, J=8.4\end{array}$ & $\begin{array}{c}7.44 \\
1 \mathrm{H}, \mathrm{dd}, J=2.1,8.4\end{array}$ \\
\hline $1^{\prime \prime}$ & $\begin{array}{c}5.3 \\
1 \mathrm{H}, \mathrm{d}, J=7.5\end{array}$ & $\begin{array}{c}5.58 \\
1 \mathrm{H}, \mathrm{d}, J=7.5\end{array}$ & $\begin{array}{c}5.54 \\
1 \mathrm{H}, \mathrm{d}, J=6.9\end{array}$ & $\begin{array}{c}5.55 \\
1 \mathrm{H}, \mathrm{s}\end{array}$ & $\begin{array}{c}5.55 \\
1 \mathrm{H}, \mathrm{s}\end{array}$ \\
\hline $4^{\prime \prime}$ & - & - & - & - & $\begin{array}{c}4.72 \\
1 \mathrm{H}, \mathrm{t}\end{array}$ \\
\hline $6^{\prime \prime}$ & - & $\begin{array}{c}3.59 \\
1 \mathrm{H}, \mathrm{dd}, J=7.0,11\end{array}$ & - & $\begin{array}{c}1.13 \\
3 \mathrm{H}, \mathrm{d}, J=6\end{array}$ & $\begin{array}{c}1.13 \\
3 \mathrm{H}, \mathrm{d}, J=6\end{array}$ \\
\hline $1^{\prime \prime \prime}$ & $\begin{array}{c}5.58 \\
1 \mathrm{H}, \mathrm{s}\end{array}$ & $\begin{array}{c}5.56 \\
1 \mathrm{H}, \text { br. s }\end{array}$ & - & $\begin{array}{c}5.31 \\
1 \mathrm{H}, \mathrm{s}\end{array}$ & $\begin{array}{c}5.31 \\
1 \mathrm{H}, \mathrm{s}\end{array}$ \\
\hline $6^{\prime \prime \prime}$ & $\begin{array}{c}1.27 \\
3 \mathrm{H}, \mathrm{d}, J=6\end{array}$ & $\begin{array}{c}0.82 \\
3 \mathrm{H}, \mathrm{d}, J=6\end{array}$ & - & $\begin{array}{c}0.82 \\
3 \mathrm{H}, \mathrm{d}, J=6\end{array}$ & $\begin{array}{c}0.82 \\
3 \mathrm{H}, \mathrm{d}, J=6\end{array}$ \\
\hline $\mathrm{OCH}_{3}-3^{\prime}$ & - & $\begin{array}{c}3.86 \\
3 \mathrm{H}, \mathrm{s}\end{array}$ & $\begin{array}{c}3.83 \\
3 \mathrm{H}, \mathrm{s}\end{array}$ & - & $\begin{array}{l}3.87 \\
3 \mathrm{H}, \mathrm{s}\end{array}$ \\
\hline $\mathrm{OCH}_{3}-4^{\prime}$ & & & - & $\begin{array}{c}3.86 \\
3 \mathrm{H}, \mathrm{s}\end{array}$ & - \\
\hline $\mathrm{OCOCH}_{3}$ & & & - & - & $\begin{array}{l}2.00 \\
3 \mathrm{H}, \mathrm{s}\end{array}$ \\
\hline
\end{tabular}

Compound 2 was yellow amorphous powder; $\mathrm{mp} 225^{\circ} \mathrm{C}$. Two meta-coupled doublets at $\delta_{\mathrm{H}} 6.46$ and $6.86(J=2.0 \mathrm{~Hz})$ correlated to two methines at $\delta_{\mathrm{C}} 99.85$ and 95.05 and were assigned to C-6 and C-8, respectively (Tables 1 and 2). A methoxyl signal appeared at $\delta_{\mathrm{H}} 3.59$ and two sugars were indicated from the two anomeric protons at $\delta_{\mathrm{H}} 5.58$ and $5.56 \mathrm{ppm}$. The chemical shifts of the sugar carbons were in complete agreement with those reported for 2-O- $\alpha$-L-rhamnopyranosyl- $\beta$-D-glucopyranose (neohesperidose) [7]. All data were consistent with a flavonol glycoside which was isolated from C. droserifolia [7]. Thus, compound 2 was identified as isorhamnetin-7-O- $\beta$-D-neohesperidoside (Figure 2). 


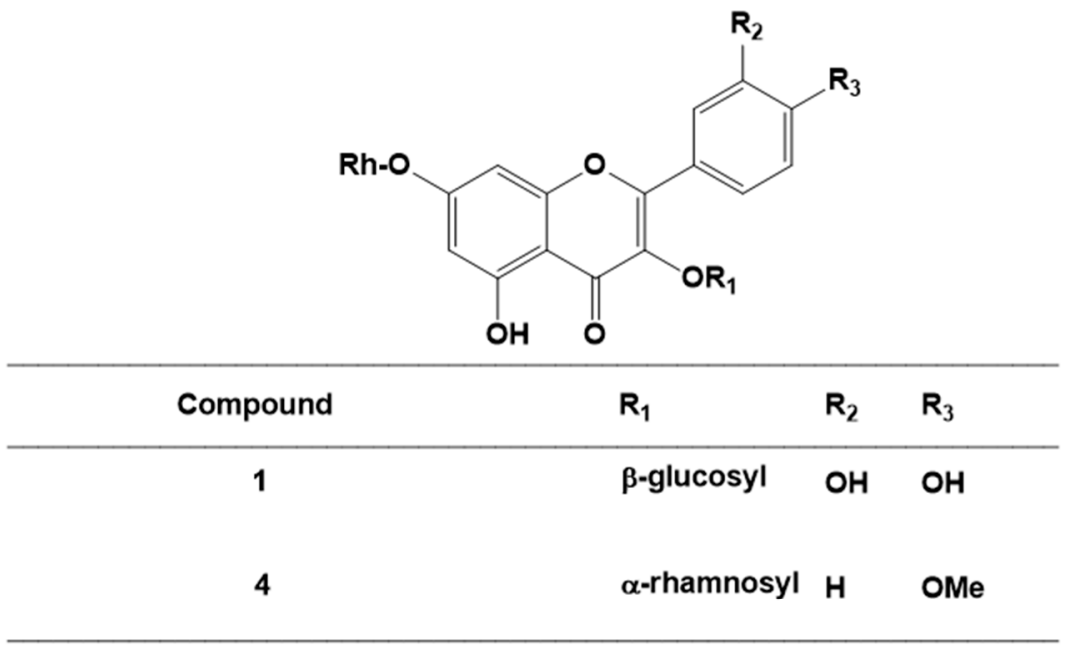<smiles>[R6]Oc1cc(O)c2c(=O)c(OCC)c(-c3ccc(O)c(OC)c3)oc2c1</smiles>

\begin{tabular}{ccl}
\hline Compound & $\mathrm{R}_{1}$ & $\mathrm{R}_{2}$ \\
\hline 2 & $\mathrm{H}$ & p-neohesperidoside
\end{tabular}

3

$\beta$-glucosyl

H

5

4"-acetylrhamnosyl $\alpha$-rhamnosyl

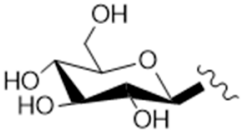

$\beta$-glucosyl

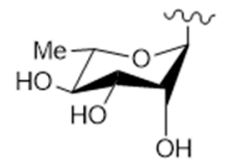

$\alpha$-rhamnosyl

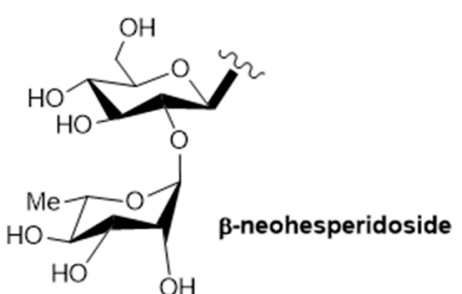

Figure 2. Chemical structures of compounds 1-5.

Compounds 3 and 4 were isolated as yellow crystalline powder; m.p. 243 and $247^{\circ} \mathrm{C}$, respectively. Their ${ }^{1} \mathrm{H}$ and ${ }^{13} \mathrm{C}-\mathrm{NMR}$ data were in agreement with those reported for isorhamnetin-3-O- $\beta$-D-glucoside and kaempferol-4'-methoxy-3,7-O- $\alpha$-dirhamnoside, respectively (Figure 2) previously isolated from C. droserifolia [11].

Compound 5 was yellow crystalline powder; m.p. $257{ }^{\circ} \mathrm{C}$. Its ${ }^{1} \mathrm{H}$ and ${ }^{13} \mathrm{C}-\mathrm{NMR}$ spectra (Tables 1 and 2) showed the characteristic signals for a quercetin nucleus and a methoxy group at $\delta_{\mathrm{H}} 3.87 \mathrm{ppm}$ and $\delta_{\mathrm{C}} 55.7 \mathrm{ppm}$. Its position was also confirmed by the upfield shift of C-2' $\left(\delta_{\mathrm{C}} 113.1 \mathrm{ppm}\right)$. Two anomeric protons $\left(\delta_{\mathrm{H}} 5.55\right.$ and $5.31 \mathrm{ppm} ; \delta_{\mathrm{C}} 101.3$ and $\left.99.4 \mathrm{ppm}\right)$ appeared as singlets and two doublets $\left(\delta_{\mathrm{H}} 1.13\right.$ and $0.82 \mathrm{ppm} ; \delta_{\mathrm{C}} 17.4$ and $\left.17.1 \mathrm{ppm}\right)$ were assigned to the two methyl groups of rhamnose moieties attached to $3-\mathrm{OH}$ and $7-\mathrm{OH}$, respectively. An acetyl group appeared 
as $(3 \mathrm{H}, \mathrm{s})$ at $\delta_{\mathrm{H}} 2.00 \mathrm{ppm}, \delta_{\mathrm{C}} 20.9$ and $169.9 \mathrm{ppm}$ (OCOCH3). All spectral data matched a flavonol glycoside previously isolated from $C$. droserifolia by members of our group [11]. Thus compound 5 was identified as isorhamnetin-3-O- $\alpha$-(4"'- acetylrhamnoside)-7-O- $\alpha$-rhamnoside (Figure 2).

\subsection{Intestinal Enzymes Inhibition}

Several enzymes are involved in diabetes management. Two of these enzymes are the intestinal enzymes $\alpha$-amylase and $\alpha$-glucosidase that are involved in the hydrolysis of starch into glucose. Thus, inhibition of these enzymes has been identified as a potentially important approach in the management of diabetes by controlling the postprandial hyperglycemia and retarding glucose absorption [4]. In this study, the in vitro $\alpha$-amylase inhibition of the aqueous extract of C. droserifolia along with compounds 1-5 were evaluated. Only compounds $\mathbf{4}$ and $\mathbf{5}$ possessed mild $\alpha$-amylase inhibitory activity with $\mathrm{IC}_{50}$ values of $152.6 \pm 35.75 \mu \mathrm{g} / \mathrm{mL}$ and $106.3 \pm 2.50 \mu \mathrm{g} / \mathrm{mL}$, respectively, compared to acarbose reference standard $\left(\mathrm{IC}_{50}=0.57 \pm 0.04 \mu \mathrm{g} / \mathrm{mL}\right)$. No inhibitory activity was observed by the $C$. droserifolia extract nor compounds 1-3. On the other hand, the $\alpha$-glucosidase enzyme inhibition assay declared that although the aqueous extract of $C$. droserifolia exerted a weak inhibitory activity, all isolated compounds showed moderate dose-dependent inhibitory activities. Among these, compounds 5 and 4 displayed the most prominent $\alpha$-glucosidase inhibitory activities with $\mathrm{IC}_{50}$ values of $86.54 \pm 3.8$ and $110.09 \pm 4.2 \mu \mathrm{g} / \mathrm{mL}$, respectively (Figure 3), compared to $14.81 \pm 0.4 \mu \mathrm{g} / \mathrm{mL}$ of acarbose.

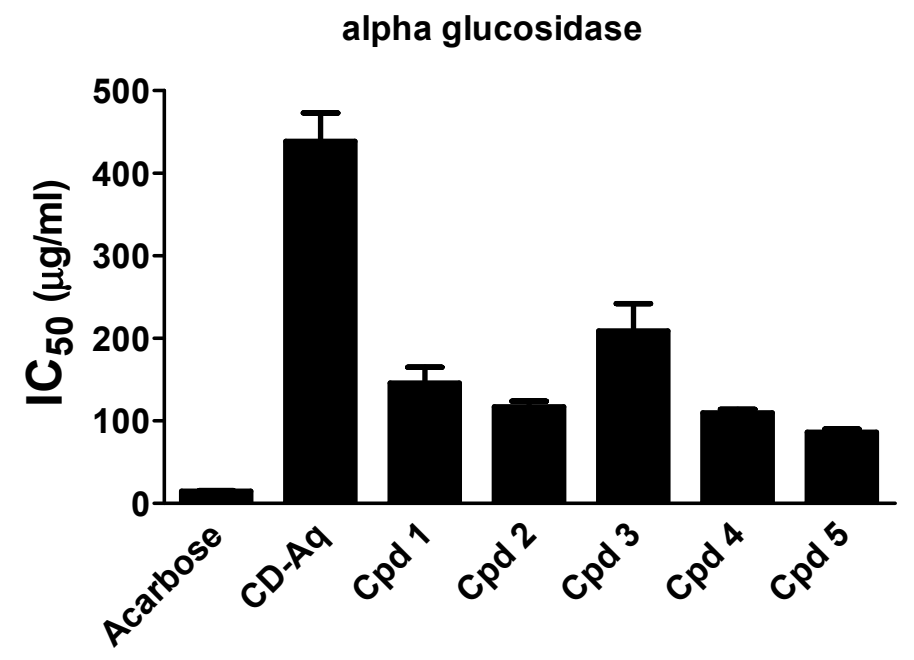

Figure 3. Alpha glucosidase inhibitory activity of the aqueous extract of Cleome droserifolia and the isolated compounds (1-5). Values are shown as mean \pm SEM of two replicates. CD-Aq, aqueous extract; Cpd, compound.

\subsection{Dipeptidyl Peptidase IV (DPPIV) Inhibition}

Dipeptidyl peptidase IV (DPPIV) enzyme inactivates the incretins, GLP-1 and GIP. Thus, glucose tolerance in diabetes patients is improved through inhibiting DPPIV by enhancing glucose-dependent insulin release in addition to stimulating $\beta$-cell proliferation [3]. The inhibition potential of the $C$. droserifolia extract and isolated compounds was measured in vitro as depicted in Figure 4 . Results revealed that the extract and the isolated compounds exerted high inhibitory activities. Of notice, the isolated compounds (1-4) had $\mathrm{IC}_{50}$ values of $0.194 \pm 0.06,0.573 \pm 0.03,0.345 \pm 0.02$ and $0.281 \pm 0.05 \mu \mathrm{g} / \mathrm{mL}$ that were comparable to the commercially available DPPIV inhibitor, vildagliptin ( $\mathrm{IC}_{50} 0.154 \pm 0.02 \mu \mathrm{g} / \mathrm{mL}$ ). 
DPPIV

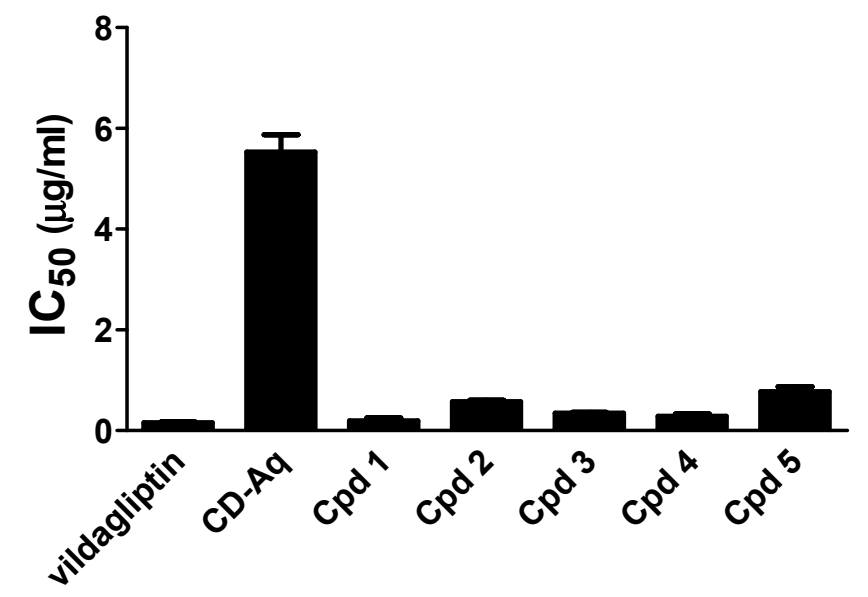

Figure 4. Dipeptidyl peptidase IV (DPPIV) inhibitory activity of the aqueous extract of Cleome droserifolia and the isolated compounds (1-5). Values are shown as mean \pm SEM of two replicates. CD-Aq, aqueous extract; Cpd, compound.

\subsection{Aldose Reductase Inhibition}

The aldose reductase enzyme is crucial in the development of vascular and neurological complications of diabetes [4]. Thereby targeting this enzyme is of great value in treating diabetes complications such as neuropathy, nephropathy and retinopathy. The incubation of either the aqueous extract of $C$. droserifolia or the isolated compounds (1-5) with aldose reductase enzyme induced a remarkable decrease in its activity (Figure 5). The $\mathrm{IC}_{50}$ values were recorded at $30.51 \pm 1.95,5.45 \pm 0.26$, $21.55 \pm 1.52,30.68 \pm 1.82$ and $77.24 \pm 3.71 \mu \mathrm{g} / \mathrm{mL}$ for the $C$. droserifolia isolated compounds (1-5), respectively. Interestingly, the reference standard quercetin $\left(\mathrm{IC}_{50} 7.77 \pm 0.43 \mu \mathrm{g} / \mathrm{mL}\right.$ ) possessed only $70 \%$ of the activity of compound 2 .

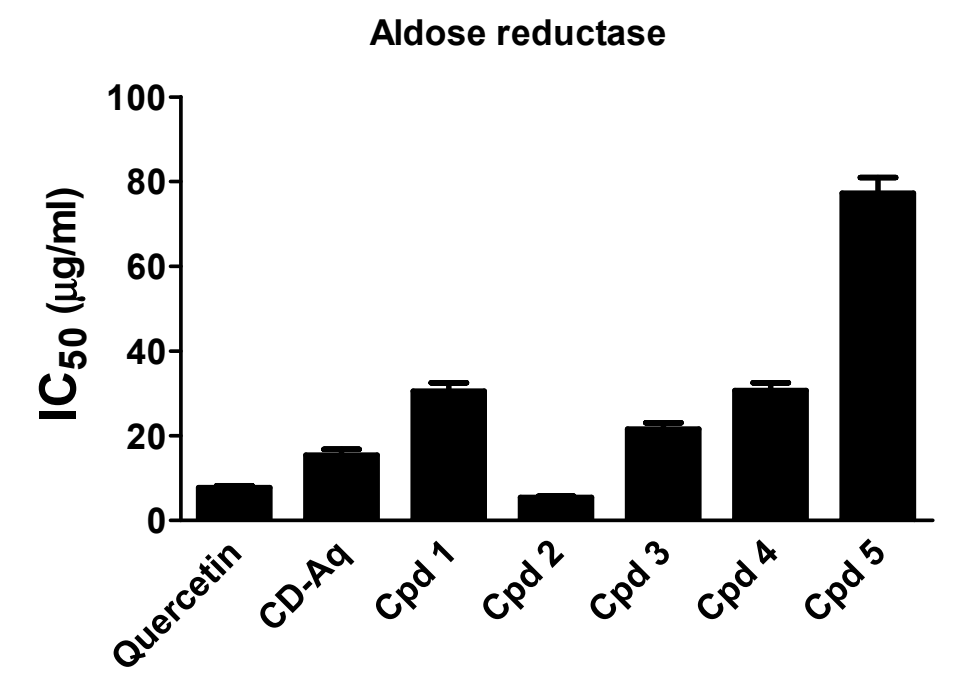

Figure 5. Aldose reductase inhibitory activity of the aqueous extract of Cleome droserifolia and the isolated compounds (1-5). Values are shown as mean \pm SEM of two replicates. CD-Aq, aqueous extract; Cpd, compound.

From the above results, it could be deduced that the folk antidiabetic potential of $C$. droserifolia aqueous extract is possibly conveyed through its major constituents of flavonol glycosides $(78 \%)$ attaining different mechanisms of action. Where the two relatively less polar methoxylated flavonol glycosides (4 and 5) contributed partly by moderately inhibiting the intestinal enzymes ( $\alpha$-amylase and $\alpha$-glucosidase) and thus could retard glucose absorption. Intriguingly, these two 
compounds showed before significant insulin-like effects in vitro by increasing basal glucose uptake [6]. Moreover, members of our research group proved previously that these compounds possessed potent cytotoxic activities against breast (MCF7), colon (HCT116), and liver (HepG2) carcinoma, where compound (5) harnessed HepG2 tumor progression in a TP53/miR-15/miR-16 dependent manner [11,18].

However, the five major flavonol glycosides could potentially mediate the antidiabetic activity of the aqueous extract through the observed remarkable inhibition of DPPIV enzyme, which was comparable to the commercial drug vildagliptin. Thus, flavonol glycosides of $C$. droserifolia could be considered as potential lead compounds for type 2 diabetes mellitus treatment possibly by prolonging the incretins actions in stimulating insulin release, augmenting $\beta$-cell proliferation and combating hyperglycemia. Previous literature reported the in vitro DPPIV inhibitory activity of flavonol glycosides (kaempferol glycosides) found in Lens culinaris [3]. Further studies also proved the in vivo DPPIV inhibitory activity of flavonoids in serum of type 2 diabetic mice [19] and normal albino rats [20], as well as their ability to increase serum GLP1 level [19]. Here we report DPPIV inhibition by kaempferol, quercetin and isorhamnetin glycosides. This might explain, at least in part, the previously reported antihyperglycemic effect of kaempferol-3,7-O- $\alpha$-dirhamnoside [21], isorhamnetin-3-O- $\beta$-D-glucoside [22] and quercetin [23] in diabetic rats.

Moreover, the aqueous extract of $C$. droserifolia possessed a potential ability in preventing diabetes complications as conveyed by the strong aldose reductase inhibitory activity of its flavonol glycosides (1-5), in particular isorhamnetin-7-O- $\beta$-D-neohesperidoside (2) and isorhamnetin-3-O- $\beta$-D-glucoside (3). Notably, compound 2 was more potent than the reference standard quercetin. While isorhamnetin-3-O- $\alpha$-(4"-acetylrhamnoside)-7-O- $\alpha$-rhamnoside (5), showed the least aldose reductase inhibitory activity as indicated in Figure 5, which may be due to presence of two $\alpha$-rhamnosyl sugars at position 3 and 7 of the isorhamnetin nucleus. While the sugar moieties in compound $\mathbf{2}$ is $\beta$-D-neohesperidosyl at position 7 only, and in compound 3 is $\beta$-D-glucosyl at position 3 only of the isorhamnetin nucleus. It was previously described that isorhamnetin-3-O- $\beta$-D-glucoside isolated from Salicornia herbacea inhibited aldose reductase and sorbitol accumulation in streptozotocin-induced diabetic rat tissues [22]. In agreement, both quercetin and naringin (a flavonoid glycoside) have shown inhibitory effects on lens aldose reductase of healthy and diabetic rats [24]. It was also reported that flavonoid glycosides especially glucosides were more efficiently absorbed from the small intestine than from the colon which led to higher plasma levels [25].

\subsection{In Vitro Antioxidant Activity}

Increased oxidative stress is involved in the pathogenesis of diabetes mellitus complications [26]. In the current study, the antioxidant capacity of the aqueous extract of $C$. droserifolia and its isolated flavonol glycosides was investigated using the 2, 2-Diphenyl-1-picrylhydrazil (DPPH) and ferric reducing antioxidant power (FRAP) assays. Tested samples exerted excellent free radical scavenging activities as measured by the DPPH method. Of these, compounds 1, 4, 5 exhibited the highest activities with $\mathrm{IC}_{50}$ values attained at $5.67 \pm 0.09,9.44 \pm 0.13$ and $11.45 \pm 0.48 \mu \mathrm{g} / \mathrm{mL}$, respectively (Figure 6a). The standard ascorbic acid had an $\mathrm{IC}_{50}$ of $1.37 \pm 0.07 \mu \mathrm{g} / \mathrm{mL}$. Strikingly, results of the FRAP assay declared that all compounds together with the aqueous extract exhibited very potent ferric reducing activity even exceeding that of ascorbic acid. In consistence with the DPPH assay, compounds 5, 1, and 4 possessed the highest activities with FRAP values of $3610 \pm 88.3,3106 \pm 52.2$ and $1812 \pm 33.2 \mu \mathrm{M}$, respectively, as compared to $685.2 \pm 1.07 \mu \mathrm{M}$ for the ascorbic acid (Figure 6b). Antioxidant effects of flavonol glycosides from different plants have been previously demonstrated [27,28]. Thus, these flavonol glycosides might contribute to the antidiabetic potential of $C$. droserifolia aqueous extract being powerful antioxidants and could offer a protective effect against diabetes complications by mitigating the oxidative stress. 


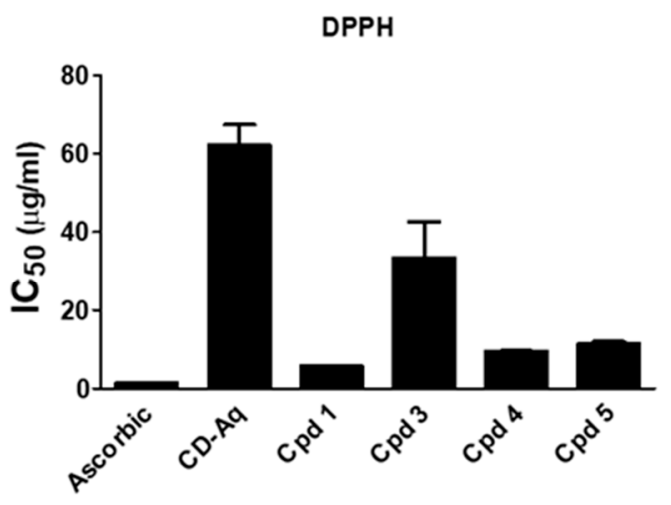

(a)

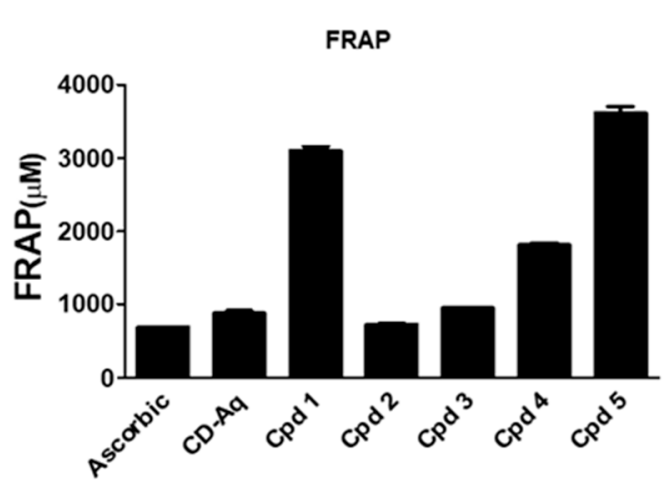

(b)

Figure 6. Antioxidant activity of the aqueous extract and isolated compounds from Cleome droserifolia. (a) DPPH radical scavenging. (b) Ferric reducing antioxidant power (FRAP). Values are shown as mean \pm SEM of two replicates. CD-Aq, aqueous extract; Cpd, compound; DPPH, 2,2-diphenyl-1-picrylhydrazyl.

\section{Materials and Methods}

\subsection{Plant Material}

The herb of Cleome droserifolia (Forssk.) Delile, Cleomaceae, was obtained from Sinai in 2015. Dr. M. Gebali (National Research Center, Egypt) authenticated the plant. A voucher specimen (No. 22.4.2015) was kept at the herbarium of the Pharmacognosy Department, Faculty of Pharmacy, Cairo University.

\subsection{General}

Alpha-glucosidase enzyme from Saccharomyces cerevisiae, $\alpha$-amylase from porcine pancreas and 2-chloro-4-nitrophenyl- $\alpha$-D-maltotrioside (CNPG3) were purchased from Sigma Aldrich. All other chemicals were purchased from UFC Biotechnology. A microplate reader (Anthos Zenyth-200RT, Cambridge, UK) was used for the spectrophotometric measurements. A Bruker NMR Spectrometer (Bruker, Yokohama, Japan) used for ${ }^{1} \mathrm{H}-\mathrm{NMR}(400 \mathrm{MHz})$ and ${ }^{13} \mathrm{C}-\mathrm{NMR}(100 \mathrm{MHz})$ analysis. Spectra were recorded in $\mathrm{CD}_{3} \mathrm{OD}$ or DMSO- $\mathrm{d}_{6}$ using tetramethylsilane (Sigma-Aldrich, St. Louis, MO, USA) as an internal standard, and chemical shift values were expressed in $\delta \mathrm{ppm}$.

\subsection{Extraction and Fractionation}

The dried powdered herb of $C$. droserifolia $(200 \mathrm{~g})$ was extracted with boiled water $(3 \times 400 \mathrm{~mL})$ by sonication at $20^{\circ} \mathrm{C}$ for $5 \mathrm{~min}$. It was allowed to stand overnight for 3 days, sonicated again for $5 \mathrm{~min}$ and filtered. The aqueous extract was concentrated and partitioned with methylene chloride $(4 \times 100 \mathrm{~mL})$. It was then fractionated with $\mathrm{H}_{2} \mathrm{O}$ and methanol (RP-18-VLC column, $\left.50 \mathrm{~g}, 8 \times 4 \mathrm{~cm}\right)$. Fractions $(100 \mathrm{~mL})$ were collected and monitored by HPLC. Compounds $\mathbf{1}-\mathbf{5}$ were eluted with $25-27 \%$, $35-40 \%, 40-50 \%, 50-50 \%$ and $45-55 \%$ methanol $/ \mathrm{H}_{2} \mathrm{O}$, respectively. The 5 compounds were further purified yielding 145, 210, 195, 230 and $130 \mathrm{mg}$ of compounds 1-5, respectively.

\subsection{HPLC Analysis of the Aqueous Extract}

An Agilent technologies 1100 series HPLC system equipped with an Agilent 1200 series quaternary pump (Agilent Technologies, Santa Clara, CA, USA), a degasser G1322A and a UV detector at $\lambda_{\max }$ $325 \mathrm{~nm}$ was used. Data acquisition was accomplished using Agilent ChemStation software (Agilent Technologies, Santa Clara, CA, USA). The aqueous extract sample $(1 \mathrm{mg} / \mathrm{mL}$ methanol $)$ was injected (20 $\mu \mathrm{L}$, injection volume) into a LiChrosphere $100 \mathrm{RP}-\mathrm{C} 18$ column $(5 \mu \mathrm{m}, 250 \mathrm{~mm} \mathrm{~L} \times 4 \mathrm{~mm} \mathrm{D}$, Merck, Germany) maintained at room temperature, preceded by RP-C18 guard column (5 $\mu \mathrm{m}$, $10 \mathrm{~mm} \mathrm{~L} \times 4 \mathrm{~mm} \mathrm{D)}$. Acetonitrile (solvent A) and $0.3 \% \mathrm{O}$-phosphoric acid in water (solvent B) were 
used as mobile phase. A continuous gradient elution (10-75\% A in B) for 25 min was carried out at a flow rate of $1.0 \mathrm{~mL} / \mathrm{min}$.

\subsection{In Vitro Antidiabetic Activity}

\subsection{1. $\alpha$-Amylase Inhibition Assay}

Inhibition of the aqueous extract and the isolated compounds on the $\alpha$-amylase enzyme activity was determined kinetically using acarbose as a standard [29]. A pre-incubation mixture was prepared which contained $40 \mathrm{mM}$ phosphate buffer ( $\mathrm{pH}$ 6.9) together with different concentrations $(10,50,100,200 \mu \mathrm{g} / \mathrm{mL})$ and $(5,20,50,100 \mu \mathrm{g} / \mathrm{mL})$ for the parent extract and the isolated compounds, respectively. A $0.2 \mathrm{U}$ of $\alpha$-amylase enzyme was added to this mixture and the plate was then incubated for $15 \mathrm{~min}$ at $37^{\circ} \mathrm{C}$. Then, 2-chloro-4-nitrophenyl maltotrioside (CNPG3) substrate was added where the final concentration was $0.9 \mu \mathrm{mole} / \mathrm{mL}$. The increase in absorbance at $405 \mathrm{~nm}$, which is proportional to the enzyme activity, was recorded for $3 \mathrm{~min}$. A control which was devoid of the test samples was also run in parallel. The $50 \%$ inhibitory concentration $\left(\mathrm{IC}_{50}\right)$ was determined and presented for the parent extract, the isolated compounds and the standard.

\subsection{2. $\alpha$-Glucosidase Inhibition Assay}

The activity of the parent extract of C. droserifolia together with the isolated compounds was assessed spectrophotometrically according to Li et al. (2009) [30] with slight modifications. In a volume of $100 \mu \mathrm{L}$ of $40 \mathrm{mM}$ phosphate buffer ( $\mathrm{pH}$ 6.9), different concentrations $(10,50,100,200 \mu \mathrm{g} / \mathrm{mL}) \mathrm{for}$ the parent extract and $(5,20,50,100 \mu \mathrm{g} / \mathrm{mL})$ for the isolated compounds were prepared. The tested samples were added to a reaction mixture in a 96-well microplate containing $20 \mu \mathrm{L}$ of the phosphate buffer and $20 \mu \mathrm{L}$ of $5 \mathrm{mM}$ p-nitrophenyl $\alpha$-D-glucopyranoside (PNP-G) in the buffer. Then $20 \mu \mathrm{L}$ of $0.4 \mathrm{U} / \mathrm{mL} \alpha$-glucosidase in the buffer were added and the plate was mixed and incubated at $37^{\circ} \mathrm{C}$ for $15 \mathrm{~min}$. After incubation, the absorbance was measured at $405 \mathrm{~nm}$ in the microplate reader. Acarbose was used as a reference compound and a control was performed without the test samples. The $\mathrm{IC}_{50}$ for test compounds as well as the standard was calculated and presented.

\subsubsection{Dipeptidyl Peptidase IV (DPPIV) Inhibition Assay}

The DPPIV Inhibitor Screening Kit (Abnova, Taipei, Taiwan) was used in accordance to the manufacturer's protocol. In this assay, DPPIV cleaved a substrate to produce a quenched fluorescent group $(\mathrm{Em} / \mathrm{Ex}=360 / 460 \mathrm{~nm})$. This cleavage was abolished in presence of a DPPIV inhibitor [3]. Vildagliptin was also run as a positive control inhibitor. To a $50 \mu \mathrm{L}$ DPPIV Enzyme Solution, we added $25 \mu \mathrm{L}$ of DPP4 Assay Buffer, vildagliptin or different concentrations of either the parent extract $(10,50,100,200 \mu \mathrm{g} / \mathrm{mL})$ or the isolated compounds $(5,20,50,100 \mu \mathrm{g} / \mathrm{mL})$. The plate was then incubated at $37^{\circ} \mathrm{C}$ for $10 \mathrm{~min}$ after which $25 \mu \mathrm{L}$ DPPIV Substrate Solution was added and measurement was done at $\mathrm{Ex} / \mathrm{Em}=360 / 460 \mathrm{~nm}$. Another measurement was recorded after further incubating the reaction at $37^{\circ} \mathrm{C}$ for $15-30 \mathrm{~min}$ and the difference between the two readings was calculated. The $\mathrm{IC}_{50}$ was determined and presented for the parent extract, the isolated compounds and the standard.

\subsubsection{Aldose Reductase Inhibition Assay}

Determination of the aldose reductase inhibitory effectiveness of the investigated samples was performed kinetically using the Aldose Reductase Inhibitor Screening Kit (Biovision, Milpitas, CA, USA), according to the manufacturer's protocol. The decrease in the absorption of NADPH at $340 \mathrm{~nm}$ was measured in a mixture containing NADPH, the enzyme and its substrate, DL-glyceraldeyde in addition to test samples [31]. Different concentrations of the parent extract $(10,50,100,200 \mu \mathrm{g} / \mathrm{mL})$ and of the isolated compounds $(5,20,50,100 \mu \mathrm{g} / \mathrm{mL})$ were used and quercetin was the reference standard in the assay. Briefly, $60 \mu \mathrm{L}$ of NADPH was added to all wells containing $10 \mu \mathrm{L}$ of either the Enzyme Assay Buffer, test samples or quercetin. A $90 \mu \mathrm{L}$ of freshly prepared Aldose Reductase Solution was then 
added and the plate was incubated protected from light at $37^{\circ} \mathrm{C}$ for $15-20 \mathrm{~min}$. After incubation, $40 \mu \mathrm{L}$ enzyme substrate in assay buffer was added and the absorbance was measured at $340 \mathrm{~nm}$ kinetically for 60-90 min at $37^{\circ} \mathrm{C}$. A background control free from the enzyme was run and subtracted from the readings. The $\mathrm{IC}_{50}$ was calculated and presented for the samples and the standard.

\subsection{In Vitro Antioxidant Activity}

\subsubsection{2,2-diphenyl-1-picrylhydrazil (DPPH) Radical Scavenging Assay}

The free radical scavenging capacity of the parent extract of $C$. droserifolia together with the isolated compounds was estimated using 2,2-diphenyl-1-picrylhydrazil (DPPH) as described previously [32]. In brief, $240 \mu \mathrm{L}$ of $0.004 \% \mathrm{DPPH}$ in methanol was added to $8 \mu \mathrm{L}$ of the parent extract and the isolated compounds at different concentrations: $(2,4,12,16 \mu \mathrm{g} / \mathrm{mL})$ and $(0.5,1,3,4 \mu \mathrm{g} / \mathrm{mL})$, respectively. The reaction mixture was mixed and incubated in dark for $30 \mathrm{~min}$ at room temperature. The absorbance was then measured at $517 \mathrm{~nm}$ against blank that was done using water instead of the plant extract. Ascorbic acid was used as the antioxidant standard and the $\mathrm{IC}_{50}$ value for samples and standard was determined.

\subsubsection{Ferric Reducing Antioxidant Power (FRAP) Assay}

The antioxidant potential of the extract and the isolated compounds was assessed according to the assay originally designed by Benzie and Strain (1996) [33] using the DetectX ${ }^{\circledR}$ Ferric Reducing Antioxidant Power (FRAPTM) Detection Kit by Arbor assays, Ann Arbor, USA. In the provided plate, $75 \mu \mathrm{L}$ of the prepared FRAP Color Solution was mixed with $20 \mu \mathrm{L}$ of either the aqueous extract $(400 \mu \mathrm{g} / \mathrm{mL})$, the isolated compounds $(200 \mu \mathrm{g} / \mathrm{mL})$, different concentrations of the standard ferrous chloride or ascorbic acid positive control. The mixture was incubated for $30 \mathrm{~min}$ at room temperature and the produced blue colored product was read at $560 \mathrm{~nm}$. The FRAP values were calculated and expressed in $\mu \mathrm{M} \mathrm{FeCl}{ }_{2}$.

\section{Conclusion}

The aqueous extract of C. droserifolia is traditionally used to treat hyperglycemia. It showed antidiabetic potential in several in vitro and in vivo studies. The RP-HPLC finger-print chromatogram of the aqueous extract showed five major peaks for flavonol glycosides which constituted $78 \%$ of the extract. In the current study, in vitro experiments proved that these five flavonol glycosides could inhibit DPPIV enzyme responsible for enhancing the insulin-releasing effects of incretins, in addition to inhibiting the intestinal enzymes involved in the hydrolysis of polysaccharides into glucose. These effects might, at least in part, represent possible mechanisms for the previously reported antidiabetic activity of $C$. droserifolia. Furthermore, these flavonol glycosides could offer protection against diabetes complications by virtue of inhibiting aldose reductase enzyme, and ameliorating the oxidative stress known to be involved in the pathogenesis of diabetes complications. However further studies are required to confirm their in vivo efficacies and to explore other potential mechanisms.

Author Contributions: Conceptualization, A.A.M. and H.H.S.; methodology, A.A.M., H.H.S., A.B.M., S.E.I.E. and H.E.-A.; validation, A.A., D.A., M.Y.A., A.A.S. and S.E.I.E.; formal analysis, A.A.M. and H.H.S.; writing-original draft preparation, A.A.M. and H.H.S.; writing-review and editing, A.A.M., H.H.S., A.A. and D.A.; supervision, H.E.; project administration, A.A.M. All authors have read and agreed to the published version of the manuscript.

Funding: The Deanship of Scientific Research at King Khalid University, Abha, Kingdom of Saudi Arabia is highly appreciated for funding this research. The grant number G.R.P. 218/39 was under the umbrella of the General Research Program. Amira Abdel Motaal was the principal investigator.

Conflicts of Interest: The authors declare no conflict of interest. 


\section{Abbreviations}

$\begin{array}{ll}\text { C. droserifolia } & \text { Cleome droserifolia } \\ \text { CNPG3 } & \text { 2-chloro-4-nitrophenyl - } \alpha \text {-D-maltotrioside } \\ \text { DPPIV } & \text { Dipeptidyl peptidase IV } \\ \text { DPPH } & \text { 2, 2-Diphenyl-1-picrylhydrazil } \\ \text { FRAP } & \text { Ferric reducing antioxidant power } \\ \text { GIP } & \text { Glucose-dependent insulinotropic polypeptide } \\ \text { GLP-1 } & \text { Glucagon-like peptide 1 } \\ \text { PNP-G } & \text { p-Nitrophenyl } \alpha \text {-D-glucopyranoside }\end{array}$

\section{References}

1. Petersmann, A.; Nauck, M.; Müller-Wieland, D.; Kerner, W.; Müller, U.A.; Landgraf, R.; Freckmann, G.; Heinemann, L. Definition, classification and diagnosis of diabetes mellitus. Exp. Clin. Endocrinol. Diabetes 2018, 126, 406. [CrossRef] [PubMed]

2. Wang, H.; Liu, T.; Huang, D. Starch Hydrolase Inhibitors from Edible Plants. Adv. Food Nutr. Res. 2013, 70, 103. [PubMed]

3. Kim, B.R.; Kim, H.Y.; Choi, I.; Kim, J.B.; Jin, C.H.; Han, A.R. DPP-IV inhibitory potentials of flavonol glycosides isolated from the seeds of lens culinaris: In vitro and molecular docking analyses. Molecules 2018, 23, 1998. [CrossRef] [PubMed]

4. Ezzat, S.M.; Motaal, A.A.; El Awdan, S.A.W. In vitro and in vivo antidiabetic potential of extracts and a furostanol saponin from Balanites aegyptiaca. Pharm. Biol. 2017, 55, 1931-1936. [CrossRef] [PubMed]

5. Moustafa, A.; Sarah, R.; Qiqa, S.; Mansour, S.; Alotaibi, M. Cleome droserifolia: An Egyptian Natural Heritage Facing Extinction. Asian J. Plant Sci. Res. 2019, 9, 14-21.

6. Motaal, A.A.; Ezzat, S.M.; Haddad, P.S. Determination of bioactive markers in Cleome droserifolia using cell-based bioassays for antidiabetic activity and isolation of two novel active compounds. Phytomedicine 2011, 19, 38-41. [CrossRef]

7. Abdel-Kader, M.S.; Alqasoumi, S.I.; Al-Taweel, A.M. Hepatoprotective constituents from Cleome droserifolia. Chem. Pharm. Bull. 2009, 57, 620-624. [CrossRef]

8. Abdel-Kawy, M.A.; El-Deib, S.; El-Khyat, Z.; Mikhail, Y.A. Chemical and Biological studies of Cleome droserifolia (Forssk.) Del. part I. Egypt. J. Biomed. Sci. 2000, 6, 204-218.

9. Aboushoer, M.I.; Fathy, H.M.; Abdel-Kader, M.S.; Goetz, G.; Omar, A.A. Terpenes and flavonoids from an Egyptian collection of Cleome droserifolia. Nat. Prod. Res. 2010, 24, 687-696. [CrossRef]

10. El-Askary, H.I. Terpenoids from Cleome droserifolia (Forssk.) Del. Molecules 2005, 10, 971-977. [CrossRef]

11. Ezzat, S.M.; Motaal, A.A. Isolation of new cytotoxic metabolites from Cleome droserifolia growing in Egypt. Z. Naturforsch. C J. Biosci. 2012, 67C, 266-274. [CrossRef] [PubMed]

12. Nassar, M.I.; Gamal-Eldeen, A.M. Potential antioxidant activity of flavonoids from Hypericum triquetrifolium Turra and Cleome droserifolia (Forssk.) Del. Bull. Fac. Pharm. Cairo Univ. 2003, 41, 107-115.

13. Motaal, A.A.; Ezzat, S.M.; El-Askary, H. Antihyperglycemic activity and standardization of the bioactive extract of cleome droserifolia growing in Egypt. Pharmacogn. J. 2014, 6, 15-21. [CrossRef]

14. Fushiya, S.; Kishi, Y.; Hattori, K.; Batkhuu, J.; Takano, F.; Singab, A.N.B.; Okuyama, T. Flavonoids from Cleome droserifolia suppress NO production in activated macrophages in vitro. Planta Med. 1999, 65, 404-407. [CrossRef] [PubMed]

15. Sharaf, M.; El-Ansari, M.A.; Saleh, N.A.M. Flavonoids of four Cleome and three Capparis species. Biochem. Syst. Ecol. 1997, 25, 161. [CrossRef]

16. Nicola, W.G.; Ibrahim, K.M.; Mikhail, T.H.; Girgis, R.B.; Khadr, M.E. Role of the hypoglycemic plant extract Cleome Droserifolia in improving glucose and lipid metabolism and its relation to insulin resistance in fatty liver. Boll. Chim. Farm. 1996, 135, 507.

17. Yang, S.S.; Mabry, T.J.; El-Fishawy, A.M.; El-Kashoury, E.A.; Abdel-Kawy, M.A.; Soliman, F.M. Flavonoids of Cleome droserifolia (Forssk.) Del. Egypt. J. Pharm. Sci. 1990, 31, 443.

18. Youness, R.A.; Assal, R.A.; Ezzat, S.M.; Gad, M.Z.; Abdel Motaal, A. A methoxylated quercetin glycoside harnesses HCC tumor progression in a TP53/miR-15/miR-16 dependent manner. Nat. Prod. Res. 2020, 34, 1475-1480. [CrossRef] 
19. Zhang, L.; Zhang, S.T.; Yin, Y.C.; Xing, S.-W.; Li, W.N.; Fu, X.Q. Hypoglycemic effect and mechanism of isoquercitrin as an inhibitor of dipeptidyl peptidase-4 in type 2 diabetic mice. RSC Adv. 2018, 8, 14967-14974. [CrossRef]

20. Parmar, H.S.; Jain, P.; Chauhan, D.S.; Bhinchar, M.K.; Munjal, V.; Yusuf, M.; Choube, K.; Tawani, A.; Tiwari, V.; Manivannan, E.; et al. DPP-IV inhibitory potential of naringin: An in silico, in vitro and in vivo study. Diabetes Res. Clin. Pract. 2012, 97, 105-111. [CrossRef]

21. de Sousa, E.; Zanatta, L.; Seifriz, I.; Creczynski-Pasa, T.B.; Pizzolatti, M.G.; Szpoganicz, B.; Silva, F.R. Hypoglycemic effect and antioxidant potential of kaempferol-3,7-O-(alpha)-dirhamnoside from Bauhinia forficata leaves. J. Nat. Prod. 2004, 67, 829-832. [CrossRef] [PubMed]

22. Lee, Y.S.; Lee, S.; Lee, H.S.; Kim, B.K.; Ohuchi, K.; Shin, K.H. Inhibitory effects of isorhamnetin-3-O- $\beta$-D-glucoside from Salicornia herbacea on rat lens aldose reductase and sorbitol accumulation in streptozotocin-induced diabetic rat tissues. Biol. Pharm. Bull. 2005, 28, 916-918. [CrossRef] [PubMed]

23. Vessal, M.; Hemmati, M.; Vasei, M. Antidiabetic effects of quercetin in streptozocin-induced diabetic rats. Comp. Biochem. Physiol. Toxicol. Pharmacol. Cbp. 2003, 135, 357-364. [CrossRef]

24. Goudarzi, M.; Zal, F.; Safari, M.; Sadeghian, S.; Mansour, M.S. Inhibitory activity of flavonoids on the lens aldose reductase of healthy and diabetic rats. Acta Med. Iran. 2006, 44, 41-45.

25. Hollman, P.C.H. Absorption, bioavailabilty, and metabolism of flavonoids. Pharm. Biol. 2004, 42, 74-80. [CrossRef]

26. Domingueti, C.P.; Dusse, L.M.S.A.; Carvalho, M.D.G.; De Sousa, L.P.; Gomes, K.B.; Fernandes, A.P. Diabetes mellitus: The linkage between oxidative stress, inflammation, hypercoagulability and vascular complications. J. Diabetes Complicat. 2016, 30, 738-745. [CrossRef]

27. Kumar, M.; Ahmad, A.; Rawat, P.; Khan, M.F.; Rasheed, N.; Gupta, P.; Sathiamoorthy, B.; Bhatia, G.; Palit, G.; Maurya, R. Antioxidant flavonoid glycosides from Evolvulus alsinoides. Fitoterapia 2010, 81, $234-242$. [CrossRef]

28. Plumb, K.; Price, R.; Williamson, G. Antioxidant properties of flavonol glycosides from tea. Redox Rep. 1999, 4, 13-16. [CrossRef]

29. Gad, M.Z.; El-Sawalhi, M.M.; Ismail, M.F.; El-Tanbouly, N.D. Biochemical study of the anti-diabetic action of the egyptian plants fenugreek and balanites. Mol. Cell. Biochem. 2006, 281, 173-183. [CrossRef]

30. Li, H.; Song, F.; Xing, J.; Tsao, R.; Liu, Z.; Liu, S. Screening and Structural Characterization of $\alpha$-Glucosidase Inhibitors from Hawthorn Leaf Flavonoids Extract by Ultrafiltration LC-DAD-MSn and SORI-CID FTICR MS. J. Am. Soc. Mass Spectrom. 2009, 20, 1496-1503. [CrossRef]

31. Nishimura, C.; Yamaoka, T.; Mizutani, M.; Yamashita, K.; Akera, T.; Tanimoto, T. Purification and characterization of the recombinant human aldose reductase expressed in baculovirus system. Biochim. Biophys. Acta 1991, 1078, 171-178. [CrossRef]

32. Abdel Motaal, A.; Shaker, S. Anticancer and Antioxidant Activities of Standardized Whole Fruit, Pulp, and Peel Extracts of Egyptian Pomegranate. Open Conf. Proc. J. 2011, 5, 41-45. [CrossRef]

33. Benzie, I.F.F.; Strain, J.J. The ferric reducing ability of plasma (FRAP) as a measure of 'antioxidant power': The FRAP assay. Anal. Biochem. 1996, 239, 70-76. [CrossRef] [PubMed]

Sample Availability: Samples of the compounds are available from the Amira Abdel Motaal.

Publisher's Note: MDPI stays neutral with regard to jurisdictional claims in published maps and institutional affiliations.

(C) 2020 by the authors. Licensee MDPI, Basel, Switzerland. This article is an open access article distributed under the terms and conditions of the Creative Commons Attribution (CC BY) license (http://creativecommons.org/licenses/by/4.0/). 